Louisiana State University

LSU Digital Commons

Faculty Publications

Department of Biological Sciences

$11-1-2015$

\title{
Short-term effects of herbicides and a prescribed fire on restoration of a shrub-encroached pine savanna
}

\author{
William J. Platt \\ Louisiana State University \\ Alex K. Entrup \\ The Nature Conservancy of Louisiana \\ Emily K. Babl \\ Louisiana State University \\ Cody Coryell-Turpin \\ Louisiana State University \\ Viet Dao \\ Louisiana State University
}

See next page for additional authors

Follow this and additional works at: https://digitalcommons.Isu.edu/biosci_pubs

\section{Recommended Citation}

Platt, W., Entrup, A., Babl, E., Coryell-Turpin, C., Dao, V., Hebert, J., Labarbera, C., Noto, J., Ogundare, S., Stamper, L., \& Timilsina, N. (2015). Short-term effects of herbicides and a prescribed fire on restoration of a shrub-encroached pine savanna. Restoration Ecology, 23 (6), 909-917. https://doi.org/10.1111/ rec. 12243

This Article is brought to you for free and open access by the Department of Biological Sciences at LSU Digital Commons. It has been accepted for inclusion in Faculty Publications by an authorized administrator of LSU Digital Commons. For more information, please contact ir@lsu.edu. 


\section{Authors}

William J. Platt, Alex K. Entrup, Emily K. Babl, Cody Coryell-Turpin, Viet Dao, James A. Hebert, Claire D. Labarbera, Jené F.L. Noto, Similoluwa O. Ogundare, Lucas K. Stamper, and Nabin Timilsina 


\title{
Short-term effects of herbicides and a prescribed fire on restoration of a shrub-encroached pine savanna
}

\author{
William J. Platt ${ }^{1,2}$, Alex K. Entrup ${ }^{3}$, Emily K. Babl ${ }^{4}$, Cody Coryell-Turpin ${ }^{4}$, Viet Dao ${ }^{1}$, James A. \\ Hebert $^{4}$, Claire D. LaBarbera ${ }^{4}$, Jené F. L. Noto ${ }^{1}$, Similoluwa O. Ogundare ${ }^{5}$, Lucas K. Stamper ${ }^{4}$, \\ Nabin Timilsina ${ }^{5}$
}

\begin{abstract}
Shrub encroachment occurring worldwide in savannas and grasslands has commonly been hypothesized to result from anthropogenically altered environments. Two disturbance-based approaches to restoration have involved: (1) application of selective herbicides to reduce density/cover of shrubs; (2) reinstatement of natural fire regimes to generate environmental conditions favoring herbaceous species. We studied short-term responses of native shrubs, vines, and grasses in a Louisiana pine savanna to herbicides followed by a prescribed fire and fire alone. Plots established in the summer, 2013, were hand-sprayed in the fall with Imazapyr and Triclopyr, Triclopyr alone, or no herbicide, then prescribed burned the following spring. Numbers of species of shrubs and vines at scales of 1 and $100 \mathrm{~m}^{2}$, numbers of stems and regrowth of stems produced by six common species of shrubs, and the number of flowering culms of perennial $C_{4}$ grasses were assessed postfire in 2014. Compared with fire alone, herbicides followed by fire resulted in (1) small reductions in species richness of shrubs and no effects on vines, (2) fewer stems comprising shrub genets, but similar postfire regrowth of resprouting shrub stems, and (3) fewer flowering culms of $\mathrm{C}_{4}$ grasses. Underground storage organs of savanna shrubs and vines survived both aboveground disturbances. Thus, single applications of herbicides followed by fires reduced, but did not reverse shrub encroachment and negatively affected grasses. Because effects of herbicides overrode those of prescribed fires, these disturbances did not act synergistically, suggesting that reinstating natural fire regimes should be a priority in restoration of savannas and grasslands.
\end{abstract}

Key words: disturbance intensity, genet size, grass flowering, postfire regrowth, shrub encroachment, species richness, underground storage organs

\section{Implications for Practice}

- Reinstating natural fire regimes should be a priority over use of herbicides to reduce shrub encroachment in savannas and grasslands because effects of herbicides are not synergistic with, but override effects of prescribed fires on ground layer vegetation.

- Within the context of a natural fire regime, applying herbicide to high densities of shrubs that tend not to burn may suppress shrubs and allow prescribed fires that mimic more extreme natural fires to enhance native herbaceous species.

- The timing of herbicide application relative to prescribed fire may be important both with respect to effects on shrub encroachment as well as native herbaceous species.

- Approaches to reducing shrub encroachment should reserve use of herbicide within the context of reinstituted natural fire regimes.

\section{Introduction}

Savannas and grasslands are changing worldwide. These biomes, which comprise almost half the terrestrial habitats on Earth, historically have had a ground layer of vegetation dominated by grasses. Currently, native woody plants are increasing in abundance and cover in most savannas and grasslands (e.g. Roques et al. 2001; Ansley \& Castellano 2006; Knapp et al. 2008; Archer 2010; Liu et al. 2013). This "shrub encroachment" is producing transitions from grass-dominated to shrub-dominated ground layers (e.g. Archer 2010; Eldridge et al. 2011). Some causal hypotheses involve global changes in climate or $\mathrm{CO}_{2}$ concentrations (e.g. Bond \& Midgley 2012; Buitenwerf et al. 2012). Other hypotheses are based on local or regional human-induced ecological changes in grazing or

Author contributions: WJP, AKE designed the study; WJP, CCT, LKS collected 2013 data; WJP, EKB, VD, JAH, CDL, JFLN, SOO, TN collected and analyzed 2014 data; WJP, EKB, VD, JAH, CDL, JFLN prepared the manuscript.

${ }^{1}$ Department of Biological Sciences, Louisiana State University, Baton Rouge, LA 70803, U.S.A.

${ }^{2}$ Address correspondence to W. J. Platt, email btplat@lsu.edu

${ }^{3}$ The Nature Conservancy of Louisiana, Northshore Field Office, Abita Springs, LA 70420, U.S.A.

${ }^{4}$ School of Renewable Natural Resources, Louisiana State University, Baton Rouge, LA 70803, U.S.A.

${ }^{5}$ Department of Biology, Chemistry, and Natural Sciences, University of Louisiana at Monroe, Monroe, LA 71209, U.S.A.

(C) 2015 Society for Ecological Restoration

doi: $10.1111 /$ rec. 12243

Supporting information at:

http://onlinelibrary.wiley.com/doi/10.1111/rec.12243/suppinfo 
fire regimes (e.g. Archer et al. 1995; Platt 1999; Van Auken 2000; Briske et al. 2005; Ward 2005; Ratajczak et al. 2014). Regardless of causes, restoration has focused primarily on reversing shrub encroachment. Approaches typically involve attempts to reduce density or cover of shrubs (e.g. Barbaro et al. 2001; Provencher et al. 2001; Paynter \& Flanagan 2004; Menges \& Gordon 2010). As a result, ecological theory has not always been applied to the management of savannas and grasslands (e.g. Briggs et al. 2005; Briske et al. 2005; Platt et al. 2015)

Pine savannas are among those habitats experiencing shrub encroachment. In the southern North American coastal plain, frequent, lightning-ignited fires in late spring/early summer historically produced landscapes with a grass-dominated ground layer containing a diversity of herbs and fire-resistant savanna pines (Platt 1999). Human use, especially this past century, resulted in fire suppression and protracted fire return intervals (Frost 2006). These changes in pine savanna fire regimes have been associated with the spread of multiple native shrubs/trees and vines, increasing local dominance by woody plants (e.g. Van Lear et al. 2005; Addington et al. 2012). Such shifts in states are not readily reversed by reinstatement of natural fire regimes (Drewa et al. 2002). Most woody species in savannas and grasslands are geoxyles with perennating underground storage organs (USOs) such as enlarged root crowns/caudices or xylopodia (Drewa et al. 2006; Simon et al. 2009; Maurin et al. 2014). Hardwoods resprout from dormant buds on USOs following stem mortality (top-kill) in fires, producing new stems and spreading clonally (Fidelis et al. 2014). Increases in shrub cover have contributed substantially to a $96 \%$ decline in these diverse, endemic-rich ecosystems (Noss et al. 2015).

Reversing shrub encroachment in pine savannas has been based in the premise that more intense disturbances should cause greater suppressive effects than natural disturbances such as fires, to which woody species have become adapted. Mechanical (e.g. roller-chopping and mowing) and chemical (herbicides) treatments have been used to reduce dense vegetation and fuels that do not carry fire. These treatments, although effective at reducing shrub cover and biomass, are controversial because they may adversely affect native plants or the soil. For example, mechanical treatments can disrupt soil and drainage patterns, and chemicals often adversely affect herbaceous species (e.g. Kaeser \& Kirkman 2010; Menges \& Gordon 2010). These treatments have been considered effective, however, for initiating restoration of shrub-encroached savannas when used in association with prescribed fire (Menges \& Gordon 2010).

We studied the effects of herbicides and prescribed fire on ground layer vegetation at The Nature Conservancy's (TNC) Abita Creek Flatwoods Preserve in eastern Louisiana. This site, which contains mesic (flatwoods) and hydric (seepage) pine savannas, is unsuitable for mechanical treatments due to sensitive wetland soils. TNC was planning to conduct trial applications of two herbicides, Imazapyr and Triclopyr ester, to assess effectiveness for use in reducing shrub encroachment. Imazapyr, which is absorbed through both leaves and roots, is considered moderately soil active (Dickens \& Wehtje 1986). It is an acetolactate synthase (ALS) inhibitor, acting on certain enzymes to prevent normal cell growth. Triclopyr ester is an auxin mimic herbicide specific to broadleaf herbs and woody plants that causes uncontrolled cell growth (Tu et al. 2001). This herbicide is not considered soil active, as it is readily adsorbed to soil (Pusino et al. 1994). Prior studies using these herbicides have shown short-term reductions in shrub cover, as well as longer-term positive responses from herbaceous species (e.g. Walker \& Silletti 2006; Miller \& Chamberlain 2008; Freeman \& Jose 2009; Iglay et al. 2010).

We experimentally evaluated short-term effects of herbicides and prescribed fires on shrubs and vines and dominant $\mathrm{C}_{4}$ grasses in the ground layer. We hypothesized that herbicide, followed by a prescribed fire, should produce larger effects on woody plants than fire alone. We reasoned that increased effects should include mortality of aboveground stems and associated dormant buds on USOs, and reduction in the sizes of shrubs and vines that were sprayed and burned, compared with those that were only burned. We further postulated that if herbicides affected entire USOs of woody plants, we should see reductions in regrowth following herbicide and fire compared with fire alone. Based on prior studies, we also predicted that herbicides should not alter species richness of shrubs and vines, and that they should likely produce negative effects on herbaceous species, particularly $\mathrm{C}_{4}$ grasses that do not have USOs.

We conducted our experimental study in 2013 and 2014. We established three sets of replicated plots in the mesic and hydric savanna and sampled species composition of shrubs and vines prior to treatment. Vegetation in two sets of plots was hand-sprayed with herbicides in the fall of 2013; an unsprayed third set was not treated with herbicides. In the spring of 2014, all three sets of plots were burned in a prescribed fire. During the summer and fall of 2014, we resampled plots to evaluate changes in species richness of native shrubs and vines and measured postfire regrowth of six abundant species of shrubs, as well as fall-flowering of dominant $\mathrm{C} 4$ perennial grasses. We used our data to assess restoration approaches using herbicide and prescribed fire treatments on shrub encroachment of pine savannas.

\section{Methods}

\section{Study Area}

The 403 ha Abita Creek Flatwoods Preserve contains pine savannas and imbedded seepages along Abita Creek in St. Tammany Parish, LA $\left(30^{\circ} 31.3^{\prime} \mathrm{N} ; 89^{\circ} 57.6^{\prime} \mathrm{W}\right)$. Overstory trees include longleaf (Pinus palustris) in uplands and slash pine (Pinus elliottii var. elliottii) in seeps/lowlands. The ground layer, dominated by $\mathrm{C} 4$ perennial grasses, contains high plant species diversity (Keddy et al. 2006). The study site was located in the northeastern section of the preserve, along upper regions of a west-facing elevation gradient from approximately $18 \mathrm{~m}$ above sea level down to Abita Creek at approximately $12 \mathrm{~m}$ above sea level. The two ultisols at the site, upland Savanna (SA) and lowland Myatt (MT) fine sandy loams, are Fragiudults; a perched water table occurs atop a fragipan $50-150 \mathrm{~cm}$ below the surface 
(Trahan et al. 1990). The local climate, summarized by Trahan et al. (1990), includes a growing season averaging 251 days, from mid-March to mid-November. Average yearly maximum and minimum temperatures in St. Tammany Parish are 25.9 and $12.7^{\circ} \mathrm{C}$, with monthly maxima around $32^{\circ} \mathrm{C}$ (June-August) and monthly minima around $4.44^{\circ} \mathrm{C}$ (December-February). Total yearly precipitation $(170.18 \mathrm{~cm})$ is seasonal, with minima in the spring and fall $(11.4-12.7 \mathrm{~cm} / \mathrm{month}$ in April-June; $7.62-10.16 \mathrm{~cm} /$ month in October-November) and maxima in winter and summer ( $15.24 \mathrm{~cm}$ in December; $17.27 \mathrm{~cm}$ in July). The last major hurricane to cross the preserve (Katrina in 2005) had little effect on the pine savannas.

\section{Field Design and Experimental Treatments}

Twelve $20 \times 20 \mathrm{~m}$ plots were established in an area of about 10 ha during the summer of 2013. Four plots were selected within each of three blocks designated a priori, two for herbicide application and one to be burned only. The four plots in each block were arranged along the elevation gradient at $1 \mathrm{~m}$ intervals from 15 (hydric seepage savanna) to $18 \mathrm{~m}$ (mesic pine savanna) above mean sea level. All plots were selected as randomly as possible, avoiding human disturbances (e.g. old logging roads and fire lanes). Each plot, with edges oriented north-south and east-west, was subdivided into four $10 \times 10 \mathrm{~m}$ subplots.

Three treatments were used in this study: (1) a mixture of Triclopyr and Imazapyr + fire; (2) Triclopyr + fire, and (3) no herbicide + fire (control). The treatment of Imazapyr + fire was not used in this study. Each herbicide treatment involved foliar application to a block of four plots (one plot at each elevation; total of four plots per treatment). The herbicides were used in a liquid form and hand-sprayed onto shrubs and vines using a backpack sprayer. Herbicides were applied in the fall of 2013, when photosynthetic products and nutrients, as well as adsorbed herbicides, were thought to be transported to USOs. Most woody plants at the site are evergreen; those that are deciduous tended to have leaves still present on stems at the time of application.

Treatment 1 (Imazapyr/Triclopyr mixture) was applied along the elevation gradient in October, 2013, to a 0.6-ha block containing four plots, one at each elevation. Staff of the TNC sprayed $30.3 \mathrm{~L}$ of a mixture of $1.5 \%$ Remedy Ultra $(60.45 \%$ active ingredient, 43.46\% acid equivalent; EPA \#62719-552), mixed with 1\% Polaris (Imazapyr 27.7\%; EPA \#228-534). The rate of application was $858 \mathrm{~mL} / \mathrm{ha}(518 \mathrm{~mL} / \mathrm{ha}$ active ingredient) for the Remedy Ultra and $572 \mathrm{~mL} / \mathrm{ha}(158 \mathrm{~mL} / \mathrm{ha}$ active ingredient) for the Polaris. Application was made with dye and $0.5 \% 90 / 10$ nonionic surfactant. Weather during application included a sustained north wind greater than $3.2 \mathrm{kph}$ (gusts to $12.9 \mathrm{kph}$ ), ambient temperature of $23.3^{\circ} \mathrm{C}$, and relative humidity of $46 \%$.

Treatment 2 (Triclopyr alone) was applied in early December, 2013 , to a second block of approximately 20 ha that contained four plots, one at each elevation. A contracted company sprayed herbicide at a rate of 3,280 mL/ha. Element 4 (Triclopyr ester, EPA \#62719-40) was mixed at $6.25 \%$ with nonionic surfactant. During that week of application, the nighttime low was $2.8^{\circ} \mathrm{C}$ and the daily high was $27.2^{\circ} \mathrm{C}$; winds were variable that week at $8.0-12.9 \mathrm{kph}$. Humidity ranged from 54 to $80 \%$.

All 12 plots were burned on 27 March, 2014, in a prescribed fire conducted on the preserve by TNC staff. This prescribed fire, ignited using drip torches, spread across the study plots as a combination of head and flanking fires. During the fire, highest/lowest recorded temperatures were $20.6^{\circ} \mathrm{C} / 8.9^{\circ} \mathrm{C}$. Dewpoint was $12.8^{\circ} \mathrm{C}$, and minimum recorded relative humidity was $61 \%$. Winds at the nearest weather station (Abita Springs, LA, U.S.A.) averaged $12.9 \mathrm{kph}$ out of the SE (gusts to $29.0 \mathrm{kph}$ ). Two days after the fire, each plot was inspected to locate unburned patches. Two plots had unburned patches about $2 \mathrm{~m}$ in diameter; these patches were excluded from study.

\section{Vegetation Sampling}

We measured species composition before and after treatment. The northeast $10 \times 10 \mathrm{~m}$ subplot of each plot was divided into one hundred $1 \mathrm{~m}^{2}$ quadrats (10 rows of 10 quadrats). During the summer and early fall (June-September) of 2013, presence/absence of woody shrubs and vines were recorded in quadrats in five rows; rows between the sampling rows were used for moving around so that sampled quadrats would not be trampled. These same quadrats were resampled in June-July, 2014. A total of 44 (2013) and 40 (2014) shrub species and 11 (2013) and 12 (2014) species of vines were recorded in all plots. Species and their occurrences are listed in Appendix S1, Supporting Information. Nomenclature of shrubs and vines followed Weakley (2012). At the end of the growing season in October, 2014, five randomly selected quadrats in each of the twelve $100 \mathrm{~m}^{2}$ plots were resampled to determine if previously recorded species were still present.

Woody shrubs in the remaining three subplots of each plot were sampled for postfire regrowth in 2014. We studied three upland species (Callicarpa americana, Ilex vomitoria, and Sassafras albidum) and three seepage species (Ilex coriacea, Magnolia virginiana, and Persea palustris). All six species produce caudices, the crowns of which contain dormant buds that resprout following fire. Five randomly located genets (root caudices and associated stems) of each species were tagged in each plot in which the species occurred. Sizes of plants were estimated based on root crown surface area. Measurements after the postfire growing season (October, 2014) included numbers of resprouting stems and for the largest stem, basal diameter, and height.

Flowering of grasses was sampled in the fall following herbicide and fire treatments. In each plot, numbers of flowering culms of 25 species of perennial $\mathrm{C}_{4}$ grasses (Appendix S1, Supporting Information) were counted in five randomly selected nonadjacent $1 \mathrm{~m}^{2}$ quadrats within the northeast subplot. Annual species, such as Panicum verrucosum, was excluded. Nomenclature of grasses followed Weakley (2012).

\section{Data Analysis}

The two herbicide treatments were separated in initial analyses. With the exception of one species (I. vomitoria), no measurements differed for the two herbicides, and so they were grouped 
for further analyses. Our hypotheses thus focus on differences between shrubs that were sprayed and burned and only burned.

We determined effects of herbicides on species richness at two scales. Species recorded in $1 \mathrm{~m}^{2}$ quadrats were used to estimate mean numbers of species in $1 \mathrm{~m}^{2}$ quadrats and in $100 \mathrm{~m}^{2}$ subplots before and after treatment. We conducted Student's $t$-tests comparing effects of herbicides + fire versus fire alone on numbers of species at small and large scales using the $100 \mathrm{~m}^{2}$ plot as the unit of replication. Because multiple tests were conducted on data from the same field measurements, we used a Bonferroni adjustment of the error rate $(\alpha=0.01)$.

Analyses were conducted on resprouting shrubs. We estimated surface area of the root crown of each plant as an ellipse using two diameters of root crowns measured at right angles. Mean basal areas $( \pm \mathrm{SE})$ ranged from $36.1 \pm 5.0$ (S. albidum) to $1,848 \pm 489.8$ ( $M$. virginiana). The distribution of root crown sizes was skewed toward large surface areas, so we transformed data using $\log _{10}$ (root crown area) to normalize the data. We compared variances to determine if they were similar in the two sets of plots, then conducted Student's $t$-tests to compare sizes of plants. There were no significant differences between sizes of root crowns of any species $(t=0.301-1.773 ; p=0.084-0.767)$ in the plots that were sprayed, then burned and only burned, so we assumed that plants of a species exposed to different treatments were similar in size.

We compared numbers of live stems of shrubs that were sprayed, then burned to those of shrubs that were only burned. For analyses, we used individual shrubs within plots that were sprayed with herbicide, then burned or only burned as the units of measurement. We used an $F$-test to determine if variances were significantly different. Based on results of that test, we then used a Student's $t$-test with equal or unequal variances to test for significant effects of herbicides on numbers of stems. We used a Bonferroni adjustment of the error rate $(\alpha=0.01)$ for all $t$-tests. We also assessed effects of herbicides on regrowth of shrub stems using linear regression to obtain relationships between basal diameter and length of largest stems of shrub genets in each treatment. We graphically compared slopes for genets of each species that were herbicided, then burned, and only burned as an indication of patterns of regrowth (length of stem) relative to stem basal diameter.

We compared mean numbers per $\mathrm{m}^{2}$ of flowering culms of perennial $\mathrm{C}_{4}$ grasses in plots that were herbicided, then burned and in plots that were only burned. We summed over species in each $1 \mathrm{~m}^{2}$ quadrat and then averaged over the five quadrats in each plot. We conducted $t$-tests with a nonadjusted error rate $(\alpha=0.05)$.

\section{Study Limitations}

We recognize limits imposed by the empirical context of this study. We conducted this study in a single pine savanna preserve. Herbicide treatments were applied once, to blocks in the preserve, rather than randomly to plots. These preset blocks also restricted the numbers of plots that could be established without introducing confounding effects, such as prior human disturbances (e.g. fire lanes and old logging roads) and thus sample sizes were limited. There was also a single prescribed fire, conducted when preserves in the region often are prescribed burned, rather than when fires would have most likely occurred based on climate (e.g. Platt et al. 2015). The experimental treatments were not replicated. As a consequence of these limitations, our results are generalizable to the extent that these limits to design and implementation do not affect this study. Similar limits occur in many empirical restoration studies (e.g. Paynter \& Flanagan 2004).

\section{Results}

\section{Numbers of Species of Shrubs and Vines}

Estimated mean numbers of shrubs and vines in $100 \mathrm{~m}^{2}$ subplots ranged from $15-26$ in 2013 to $10-19$ in 2014. On average slightly fewer species were present in 2014 than in 2013 (Table 1). There were no significant effects of the treatments on estimated numbers of species in subplots in either 2013 or 2014 (Table 1). Nonetheless, analyses indicated that mean decreases in estimated species numbers per subplot (herbicide + fire: $5.5 \pm 1.5$ [standard error]; fire alone: $2.5 \pm 1.3$ ) approached significance $\left(T_{1,10}=1.74 ; p=0.056\right)$, suggesting greater reductions in numbers of species in subplots treated with fire + herbicides than in subplots treated with fire alone.

We examined subplots to explore reasons for reductions in numbers of species. Some losses of species in sprayed, then burned and burned only subplots between 2013 and 2014 resulted from fires killing small juveniles of less fire-tolerant pines (i.e. loblolly [Pinus taeda] or slash pines). Most other losses of species resulted when there was a single small individual in a subplot in 2013 and that individual was not present in 2014; these losses occurred only in plots that were sprayed, then burned. For example, individuals of Ilex opaca and Quercus falcata were recorded as small juvenile plants in a single subplot prior to herbiciding, but were not relocated after the subplots were sprayed and burned (Appendix S1, Supporting Information).

Somewhat different patterns occurred at small scales. Numbers of species of shrubs and vines, which were often intermixed in the $1 \mathrm{~m}^{2}$ quadrats, averaged approximately 3 and 1 , respectively, varying from $0-8$ (shrubs) and 0-5 (vines). Effects of spraying and burning and burning alone on numbers of shrub and vine species were similar at scales of $1 \mathrm{~m}^{2}$ (Table 1). On average, comparing 2014-2013, slightly more shrub species were present in burned only quadrats and slightly fewer species were present in herbicided, then burned quadrats (Table 1). Analyses indicated that differences in mean changes in numbers of species per quadrat for the two treatments (herbicide + fire: $-0.64 \pm 0.11$ [standard error]; fire alone: $+0.16 \pm 0.38)$ approached significance $\left(T_{1,10}=2.69\right.$; $p=0.011)$. This suggested loss of species in quadrats treated with fire + herbicides, but gains of species in quadrats treated with fire alone. The losses in sprayed, then burned plots occurred when common species were small plants in 2013. Gains resulted from germination after fires, as for example, suffructescent species of Hypericum (Appendix S1, Supporting Information). 
Table 1. Effects of herbicides on numbers of species of shrubs and vines. Mean number of species ( \pm standard error) and sample sizes are presented for woody plants and vines in $100 \mathrm{~m}^{2}$ subplots and $1 \mathrm{~m}^{2}$ plots in 2013 (before treatment) and 2014 (after treatment). Student's $t$, degrees of freedom $(d f)$, and $p(\alpha=0.05$ ) were calculated based on sample sizes indicated in table.

\begin{tabular}{|c|c|c|c|c|c|c|c|c|c|}
\hline & & Year & Herbicide + Fire & $\mathrm{N}$ & Fire Only & $\mathrm{N}$ & $t$ & $d f$ & $p$ \\
\hline \multirow{4}{*}{$100 \mathrm{~m}^{2}$ subplots } & Shrubs & 2014 & $13.88 \pm 1.22$ & 8 & $14.25 \pm 1.65$ & 4 & -0.229 & 1,10 & 0.412 \\
\hline & \multirow[t]{3}{*}{ Vines } & 2013 & $3.88 \pm 0.82$ & 8 & $3.75 \pm 0.48$ & 4 & 0.139 & 1,10 & 0.446 \\
\hline & & 2014 & $4.38 \pm 1.28$ & 8 & $4.00 \pm 0.71$ & 4 & 0.269 & 1,10 & 0.397 \\
\hline & & Difference & $-0.50 \pm 0.53$ & 8 & $-0.25 \pm 0.25$ & 4 & -0.436 & 1,10 & 0.336 \\
\hline \multirow{4}{*}{$1 \mathrm{~m}^{2}$ quadrats } & Shrubs & Difference & $0.64 \pm 0.11$ & 8 & $-0.16 \pm 0.38$ & 4 & 2.689 & 1,10 & 0.011 \\
\hline & \multirow[t]{3}{*}{ Vines } & 2013 & $1.03 \pm 0.31$ & 8 & $1.21 \pm 0.49$ & 4 & -0.322 & 1,10 & 0.377 \\
\hline & & 2014 & $0.85 \pm 0.75$ & 8 & $1.21 \pm 0.54$ & 4 & -0.670 & 1,10 & 0.259 \\
\hline & & Difference & $0.18 \pm 0.13$ & 8 & $0.62 \pm 0.31$ & 4 & 0.632 & 1,10 & 0.271 \\
\hline
\end{tabular}

Mean numbers of vines were not affected by treatments. Similar numbers of vines were present in subplots and quadrats that were sprayed, then burned and only burned. No comparisons were significant (Table 1). We did note small gains in species of vines in subplots in 2014 compared with 2013 (Table 1). These gains in species resulted from germination of legumes (e.g. Centrosema virginianum and Galactia volubilis) in several upland subplots following fires.

\section{Postfire responses of shrubs}

For all six shrub species, resprouting genets treated with herbicides, then burned, produced fewer stems than shrubs that were only burned. This pattern characterized all six species examined. Reduction in numbers of stems varied from $26 \%$ for Ilex coriace a to $72 \%$ for Ilex vomitoria (Table 2). These differences were significant $(\alpha=0.05)$ for all shrub species except Callicarpa americana, which also tended in the same direction, but had highly variable numbers of stems in burned only plots (Table 2).

Regrowth of stems following fire did not appear to be strongly affected by herbicides. For all species, the ranges of basal diameters and lengths of stems were similar. In addition, the relationship between stem basal diameter and length of the largest stems, depicted in Figure 1, was similar in plots that were herbicided, then burned and plots that were only burned for five of the six species (all except I. vomitoria).

Ilex vomitoria appeared to be more affected by herbicides than the other species of shrubs. Stems of I. vomitoria in herbicided plots tended to have smaller basal diameters, but to be of similar lengths than stems in burned only plots. Consequently, slopes were much steeper (more than twice as steep) for herbicided and burned plants than for burned only plants (Fig. 1). We also noted that $I$. vomitoria tended to have deformed branches and leaves much more often than other species. In addition, many entire genets of this species were dead when we initiated this study, and mortality of I. vomitoria contributed to the differences in species composition of sprayed, then burned and burned only treatments at both 100 and $1 \mathrm{~m}^{2}$ scales. These patterns were most often noted in plots treated with the combination of Triclopyr and Imazapyr.

\section{Postfire Responses of $\mathrm{C}_{4}$ Grasses}

Postfire flowering of perennial $\mathrm{C}_{4}$ grasses differed among plots receiving the two treatments. The fall following treatments, almost 40 flowering culms per $\mathrm{m}^{2}$ were noted in plots that were only burned. In plots that were sprayed and burned, there were, on average, $42 \%$ fewer flowering culms. Although the $\mathrm{C}_{4}$ grass species differed in uplands and seepages, similar patterns occurred at the different elevations. On average, flowering was reduced in both upland (45\%) and seepage (38\%) plots that were sprayed and burned compared with only burned.

\section{Discussion}

Results of this study of a shrub-encroached pine savanna indicate that a fall foliar application of herbicides followed by a spring prescribed fire results in greater effects on woody plants than burning alone. Nonetheless, most increases in effects were small. Mean numbers of species of shrubs, but not vines, were slightly reduced at scales of 1 and $100 \mathrm{~m}^{2}$. Thus, our hypothesis of no effects of herbicides on species richness was not completely supported; some less abundant species of shrubs, but no vines, disappeared from herbicided plots. This result suggests that caution may be needed if rare woody species are present in shrub-encroached savannas and grasslands. As hypothesized, herbicides caused mortality of stems and associated buds on USOs. The numbers of resprouting stems comprising genets were reduced in plots sprayed and burned, but increased in plots only burned. exception to the pattern of small effects occurred for Ilex vomitoria. The combination of Imazapyr and Triclopyr killed most I. vomitoria, and surviving I. vomitoria exhibited residual herbicide effects.

Our results suggest an explanation for one important result of similar studies of herbicide effects on shrubs. Transient reductions in woody plant cover following herbicide application have occurred in studies of pine savannas and grasslands (e.g. Brockway \& Outcalt 2000; Provencher et al. 2001; Miller \& Chamberlain 2008; Freeman \& Jose 2009; Hutchinson \& Langeland 2010; Iglay et al. 2010; Addington et al. 2012). Based on 
Table 2. Effects of herbicides on postfire regrowth of groundcover shrubs and flowering of perennial $\mathrm{C}_{4}$ grasses. Mean number of stems ( \pm standard error), sample sizes, and percent reduction are presented for genets of six of the most common species of woody plants and numbers of flowering culms of perennial $\mathrm{C}_{4}$ grasses in $1 \mathrm{~m}^{2}$ plots. For shrubs, Student's $t$, degrees of freedom $(d f)$, and $p(\alpha=0.01)$ were calculated based on sample sizes in table and equal (Ilex coriacea, Magnolia virginiana, Sassafras albidum) or unequal (Callicarpa americana, Ilex vomitoria, Persea palustris) variances. For $\mathrm{C}_{4}$ perennial grasses, Student's $t, d f$, and $p(\alpha=0.05)$ were calculated based on sample sizes in table and equal variances. Grass species included are listed in Appendix S1.

\begin{tabular}{|c|c|c|c|c|c|c|c|c|}
\hline Species & Herbicide + Fire & $\mathrm{N}$ & Fire Only & $\mathrm{N}$ & Percent Reduction & $t$ & $d f$ & $p$ \\
\hline Callicarpa americana & $2.05 \pm 0.36$ & 8 & $4.63 \pm 1.63$ & 20 & 56 & -1.465 & 1,8 & 0.091 \\
\hline Ilex coriacea & $5.60 \pm 0.52$ & 15 & $7.53 \pm 1.52$ & 40 & 26 & -1.800 & 1,53 & 0.039 \\
\hline Magnolia virginiana & $6.25 \pm 1.03$ & 10 & $11.70 \pm 2.04$ & 20 & 47 & -2.656 & 1,28 & 0.006 \\
\hline Persea palustris & $3.70 \pm 0.41$ & 15 & $5.67 \pm 1.28$ & 30 & 35 & -1.781 & 1,19 & 0.045 \\
\hline Sassafras albidum & $1.60 \pm 0.17$ & 10 & $2.60 \pm 0.16$ & 20 & 38 & -3.761 & 1,28 & $<0.001$ \\
\hline
\end{tabular}
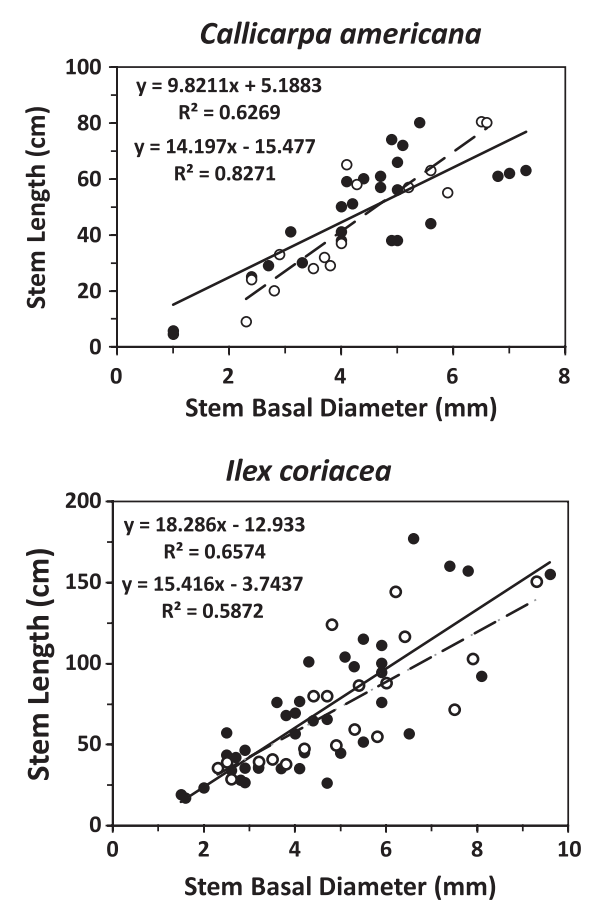

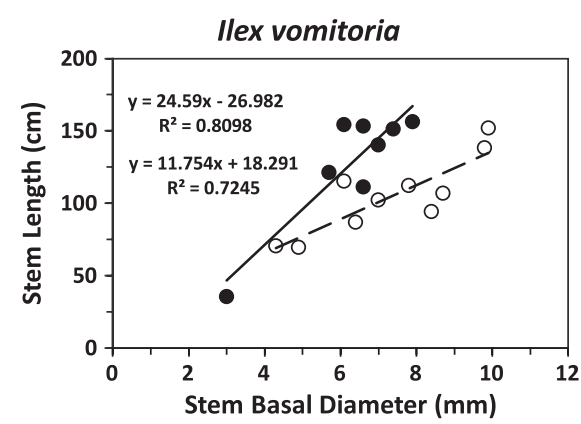

Magnolia virginiana

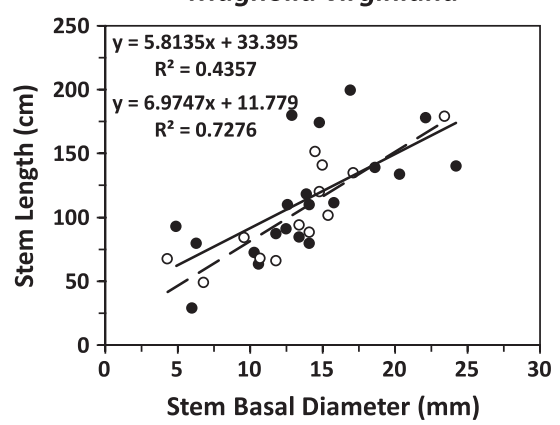

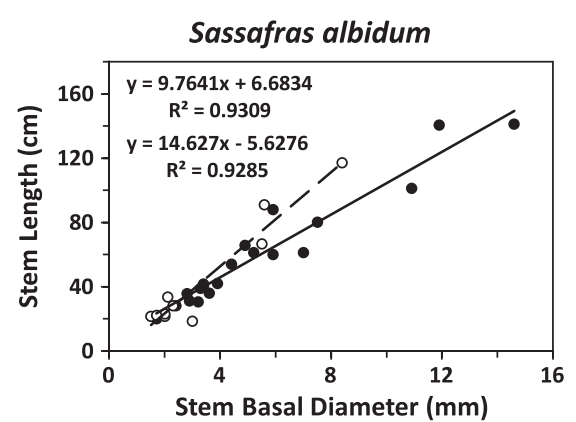

Persea palustris

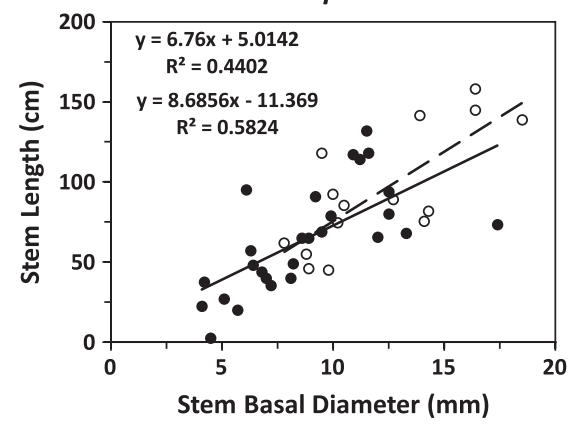

Figure 1. Relationship between basal diameter $(\mathrm{mm})$ and length of tallest stems $(\mathrm{cm})$ produced by resprouting shrubs at the end of the postfire growing season. Upper: upland shrubs (Callicarpa americana, Ilex vomitoria, Sassafras albidum). Lower: seepage shrubs (Ilex coriacea, Magnolia virginiana, Persea palustris). For each graph, closed circles indicate plants that were herbicided, then burned, and open circles indicate plants that were only burned. Linear regressions are indicated by fire (solid line: herbicide + fire; dashed line: fire only). Upper and lower regression equations indicate herbicide + fire and fire only, respectively.

our field observations, such reductions likely result from mortality of those sections of USOs immediately associated with sprayed stems, rather than more widespread depressant effects on entire USOs, particularly more deeply buried sections. Postfire regrowth (basal diameter-stem height relationships) from surviving dormant buds was similar in sprayed and burned plots and plots that were only burned. In all plots, woody plant stems were $1-2 \mathrm{~m}$ tall by the end of the postfire growing season. Thus, our original hypothesis that herbicides would suppress regrowth of stems was not supported. A single foliar application of herbicides, at the rates applied in this and other studies, opens pine savannas through stem mortality that reduces sizes of genets, but does not reverse shrub encroachment by reducing shrub density.
Woody plants in savannas and grasslands have USOs resistant to natural aboveground disturbances such as grazing and fires. Once plants reach some threshold size, dormant buds on USOs readily regenerate top-killed aboveground structures (Olson \& Platt 1995). Responses often involve increased numbers of stems, producing an often densely packed shrub growth form with increased cover and biomass (Drewa et al. 2002, 2006; Hmielowski et al. 2014). Such capabilities form the basis for in situ hypotheses that shrub encroachment results from alteration of disturbance regimes that enable shrubs to enter this fire-resistant stage (e.g. Platt 1999; Van Auken 2000; Briske et al. 2005; Ward 2005; Archer 2010; Ratajczak et al. 2014). Our field observations suggest that foliar application of 
herbicides constitutes partially lethal disturbances, killing parts of the USO associated with the sprayed aboveground stems. Other parts of the USOs appear unaffected, and these parts appear to function similarly to unsprayed plants of similar size. Further study of USOs and bud dynamics of woody plants in savannas should be useful. Basing such study in life history theory addressing evolutionary adaptation to recurrent aboveground disturbances (e.g. Bellingham \& Sparrow 2000; Bond \& Midgley 2003; Klimešova \& Klimeš 2007) might result in more effective approaches to shrub encroachment.

Studies should also explore effects of treatments on species lacking USOs. Like woody species, perennial $\mathrm{C}_{4}$ grasses respond differently to fires and herbicide. Grasses with $\mathrm{C}_{4}$ photosynthetic pathways exhibit increased biomass and flowering when fires occur during the times when they would have been burned by natural lightning fires (e.g. Streng et al. 1993). Foliar application of herbicides, as shown in this study and others (e.g. Walker \& Silletti 2006; Kaeser \& Kirkman 2010), has negative effects on grasses relative to prescribed fires alone. Herbicides thus appear to increase disturbance intensity on multiple groups of species, thereby changing savannas and grasslands in unanticipated ways.

Combining different goals in approaches to restoration may not produce synergistic effects. One approach to restoration in shrub-encroached savannas and grasslands is to combine herbicide with prescribed fire. These restoration actions have different goals: (1) reductions in encroaching woody species (i.e. damaging/killing woody plants via herbicides targeting these species), and (2) restoring environmental conditions that resemble those occurring historically (i.e. benefitting native herbaceous and suffructescent species via prescribed fires that mimic historical lightning fires). Notwithstanding the study limitations, our results suggest that short-term effects of herbicide are likely to override effects that result from reestablishment of natural environmental conditions using prescribed fire. Such overriding effects have been noted previously (e.g. see review in Menges \& Gordon 2010). Damage of woody plants has been suggested, nonetheless, to result in slow recovery, providing a window of time during which prescribed fires can be used to enhance native herbaceous species. We propose that the reverse order be considered. Use of herbicides to depress shrub encroachment in savannas and grasslands might well be more effective if conducted within the context of long-term restoration plans based in prescribed fire (also see Briske et al. 2005; Ansley \& Castellano 2006). We emphasize that such plans should be focused on fire regimes to which native floras are adapted, not anthropogenic fire regimes.

Restoration practices that involve the use of herbicide have typically been conducted with little attention to characteristics of fire regimes beyond reinstituting recurrent fires. Reinstatement of natural fire regimes has been proposed as a primary restoration action in shrub-encroached pine savannas because fire influences both woody and herbaceous plants (e.g. Platt 1999; Drewa et al. 2002; Reinhart \& Menges 2004; Platt et al. 2006; Gonzalez-Benecke et al. 2015). Prescribed fires that occur in the fire season (sensu Platt et al. 2015), after underground resources have been used to initiate aboveground growth, but before new resources are translocated below-ground, have been hypothesized to have maximum depressant effects on USOs of woody plants (e.g. Glitzenstein et al. 1995; Drewa et al. 2002, 2006), as well as maximum enhancement of $\mathrm{C}_{4}$ grasses (Streng et al. 1993; Fill et al. 2012). Thus, spraying of shrubs and vines after such fires might kill resprouting stems and damage USOs before new underground buds are produced. Such postfire timing of herbicide application might be most effective if conducted within a program of frequent prescribed fires (every $1-2$ years in the fire season) to reduce accumulation of belowground resources by USOs. Further study is needed, particularly because such timing of herbicide application could negatively affect herbaceous species.

Alternatives to treatments such as herbicide should also be explored. For example, increased intensity of fire should increase effects on shrubs. In pine savannas shed needles of longleaf pine are highly pyrogenic, burning at high temperatures for longtime intervals, and thus increasing heat at and below ground level (Platt 1999; Ellair \& Platt 2013; Gagnon et al. 2015). Such fires, especially when conducted within the fire season, have been shown to reduce resprouting of shrubs, especially those that are small or have buds at/near the soil surface (Olson \& Platt 1995; Drewa et al. 2002). We suggest that fire regimes with at least some of the fires mimicking such extreme conditions should be integral to long-term restoration of savannas and grasslands.

\section{Acknowledgments}

We thank the Louisiana Nature Conversancy for permission to conduct research at the Abita Creek Flatwoods Preserve and for funding/conducting treatments (herbiciding, fires) used in this field experiment. Latimore Smith facilitated the study; Bill Rivers conducted the prescribed fires. We thank Marc Pastorek for field assistance. We also thank the LBRN program and especially Terri Gilbert for making it possible for SO \& NT to participate in the study. Support in 2013 and 2014 was provided by the Louisiana Biomedical Research Network as part of an Institutional Development Award (IDeA) from the National Institute of General Medical Sciences of the National Institutes of Health (grant number P20GM103424) and by the Louisiana Board of Regents Support Fund. Additional support for CCT, LKS, EKB, VD, JAH, CDL, JFLN was provided through the LSU Department of Biological Sciences undergraduate teaching program. Order of authorship after WJP and AKE is alphabetical.

\section{LITERATURE CITED}

Addington RN, Greene TA, Elmore ML, Prior CE, Harrison WC (2012) Influence of herbicide site preparation on longleaf pine ecosystem development and fire management. Southern Journal of Applied Forestry 36:173-180

Ansley RJ, Castellano MJ (2006) Strategies for savanna restoration in the southern Great Plains: effects of fire and herbicides. Restoration Ecology 14:420-428

Archer SR (2010) Rangeland conservation and shrub encroachment: new perspectives on an old problem. Pages 53-97. In: du Toit JT, Kock R, Deutsch $\mathrm{J}$ (eds) Wild rangelands: conserving wildlife while maintaining livestock in semi-arid ecosystems. Wiley-Blackwell, Oxford, United Kingdom 
Archer SR, Schimel DS, Holland EA (1995) Mechanisms of shrubland expansion: land use, climate or $\mathrm{CO}_{2}$ ? Climatic Change 29:91-99

Barbaro L, Dutoit T, Cozic P (2001) A six-year experimental restoration of biodiversity by shrub-clearing and grazing in calcareous grasslands of the French Prealps. Biodiversity and Conservation 10:119-135

Bellingham PJ, Sparrow AD (2000) Resprouting as a life history strategy in woody plant communities. Oikos 89:409-416

Bond WJ, Midgley GF (2003) The evolutionary ecology of sprouting in woody plants. International Journal of Plant Sciences 164:973-982

Bond WJ, Midgley GF (2012) Carbon dioxide and the uneasy interactions of trees and savannah grasses. Philosophical Transactions of the Royal Society B 367:601-612

Briggs JM, Knapp AK, Blair JM, Heisler JL, Hoch GA, Lett MS, McCarron JK (2005) An ecosystem in transition: causes and consequences of the conversion of mesic grassland to shrubland. BioScience 55:243-254

Briske DD, Fuhlendorf SD, Smiens FE (2005) State-and-transition models, thresholds, and rangeland health: a synthesis of ecological concepts and perspectives. Rangeland Ecology \& Management 58:1-10

Brockway DG, Outcalt KW (2000) Restoring longleaf pine wiregrass ecosystems: hexazinone application enhances the effects of prescribed fire. Forest Ecology and Management 137:121-138

Buitenwerf R, Bond WJ, Stevens N, Trollope WSW (2012) Increased tree densities in South African savannas: $>50$ years of data suggests $\mathrm{CO}_{2}$ as a driver. Global Change Biology 18:675-684

Dickens R, Wehtje G (1986) Mobility and soil solution characteristics of Imazapyr (Arsenal) and sulfometuron methyl (Oust) in Alabama soils. Proceedings of the Southern Weed Science Society 39:368

Drewa PB, Platt WJ, Moser EB (2002) Fire effects on resprouting of shrubs in southeastern longleaf pine savannas. Ecology 83:755-767

Drewa PB, Thaxton JM, Platt WJ (2006) Responses of root-crown bearing shrubs to differences in fire regimes in Pinus palustris (longleaf pine) savannas: exploring old-growth questions in second-growth systems. Applied Vegetation Science 9:27-36

Eldridge DJ, Bowker MA, Maestre FT, Roger E, Reynolds JF, Whitford WG (2011) Impacts of shrub encroachment on ecosystem structure and functioning: towards a global synthesis. Ecology Letters 14:709-722

Ellair DP, Platt WJ (2013) Fuel composition influences fire characteristics and understory hardwoods in pine savannas. Journal of Ecology 101:192-201

Fidelis A, Appezzato-da-Gloria B, Pillar VD, Pfadenhauer J (2014) Does disturbance affect bud bank size and belowground structures diversity in Brazilian subtropical grasslands? Flora 209:110-116

Fill JM, Welch SM, Waldron JL, Mousseau TA (2012) The reproductive response of an endemic bunchgrass indicates historical timing of a keystone process. Ecosphere 3:art61

Freeman JE, Jose S (2009) The role of herbicide in savanna restoration: effects of shrub reduction treatments on the understory and overstory of longleaf pine flatwoods. Forest Ecology and Management 257:978-986

Frost CC (2006) History and future of the longleaf pine ecosystem. Pages 9-42. In: Jose S, Jokela EJ, Miller DL (eds) The longleaf pine ecosystem: ecology, silviculture, and restoration. Springer, New York

Gagnon PR, Passmore HA, Slocum MG, Myers JA, Harms KE, Platt WJ, Paine CET (2015) Fuels and fires influence vegetation via above- and below-ground pathways in a high-diversity plant community. Journal of Ecology (in press) DOI: 10.1111/1365-2745.12421

Glitzenstein JS, Platt WJ, Streng DR (1995) Effects of fire regime and habitat on tree dynamics in north Florida longleaf pine savannas. Ecological Monographs 65:441-476

Gonzalez-Benecke CA, Samuelson LJ, Stokes TA, Cropper WP, Martin TA, Johnsen KH (2015) Understory plant biomass dynamics of prescribed burned Pinus palustris stands. Forest Ecology and Management 344:84-94

Hmielowski TL, Robertson KM, Platt WJ (2014) Influence of season and method of topkill on resprouting characteristics and biomass of Quercus nigra saplings from a southeastern U.S. pine-grassland ecosystem. Plant Ecology 215:1221-1231
Hutchinson JT, Langeland KA (2010) Evaluation of aerial herbicide application for reduction of woody vegetation in a floodplain marsh. Journal of Aquatic Plant Management 48:40-46

Iglay RB, Leopold BD, Miller DA, Burger LW Jr (2010) Effect of plant community composition on plant response to fire and herbicide treatments. Forest Ecology and Management 260:543-548

Kaeser MJ, Kirkman LK (2010) The effects of pre- and post-emergent herbicides on non-target native plant species of the longleaf pine ecosystem. Journal of the Torrey Botanical Society 137:420-430

Keddy PA, Smith L, Campbell DR, Clark M, Montz G (2006) Patterns of herbaceous plant diversity in southeastern Louisiana pine savannas. Applied Vegetation Science 9:17-26

Klimešova J, Klimeš L (2007) Bud banks and their role in vegetative regeneration-a literature review and proposal for simple classification and assessment. Perspectives in Plant Ecology, Evolution, and Systematics 8:115-129

Knapp AK, Briggs JM, Collins SL, Archer SR, Bret-Harte MS, Ewers BE, et al. (2008) Shrub encroachment in North American grasslands: shifts in growth form dominance rapidly alters control of ecosystem carbon inputs. Global Change Biology 14:615-623

Liu F, Archer SR, Gelwick F, Bai E, Boutton TW, Wu XB (2013) Woody plant encroachment into grasslands: spatial patterns of functional group distribution and community development. PLoS One 8:e84364

Maurin O, Davies TJ, Burrows JE, Daru BH, Yessoufou K, Muasya AM, van der Bank M, Bond WJ (2014) Savanna fire and the origins of the "underground forests' of Africa. New Phytologist 204:201-214

Menges ES, Gordon DR (2010) Should mechanical treatments and herbicides be used as fire surrogates to manage Florida's uplands? A review. Florida Scientist 73:147-174

Miller DA, Chamberlain MJ (2008) Plant community response to burning and herbicide site preparation in eastern Louisiana, U.S.A. Forest Ecology and Management 255:774-780

Noss RF, Platt WJ, Sorrie BA, Weakley AS, Means DB, Costanza J, Peet RK (2015) How global biodiversity hotspots may go unrecognized: lessons from the North American coastal plain. Diversity and Distributions 21:236-244

Olson MS, Platt WJ (1995) Effects of habitat and growing season fires on resprouting of shrubs in longleaf pine savannas. Vegetation 119:101-118

Paynter Q, Flanagan GJ (2004) Integrating herbicide and mechanical control treatments with fire and biological control to manage an invasive wetland shrub, Mimosa pigra. Journal of Applied Ecology 41:615-629

Platt WJ (1999) Southeastern pine savannas. Pages 23-51. In: Anderson RC Fralish JS, Baskin J (eds) The savanna, barren, and rock outcrop communities of North America. Cambridge University Press, Cambridge, United Kingdom

Platt WJ, Carr SM, Reilly M, Fahr J (2006) Pine savanna overstorey influences on ground-cover biodiversity. Applied Vegetation Science 9:37-50

Platt WJ, Orzell SL, Slocum MG (2015) Seasonality of fire weather strongly influences fire regimes in south Florida savanna-grassland landscapes. PLoS One 10:e0116952

Provencher L, Herring BJ, Gordon DR, Rodgers HL, Tanner GW, Hardesty JL, Brennan LA, Litt AR (2001) Longleaf pine and oak responses to hardwood reduction techniques in fire-suppressed sandhills in northwest Florida. Forest Ecology and Management 148:63-77

Pusino A, Liu WP, Gessa C (1994) Adsorption of triclopyr on soil and some of its components. Journal of Agricultural Food Chemistry 42:1026-1029

Ratajczak Z, Nippert JB, Brigg JM, Blair JM (2014) Fire dynamics distinguish grasslands, shrublands and woodlands as alternative attractors in the Central Great Plains of North America. Journal of Ecology 102:1374-1385

Reinhart KO, Menges ES (2004) Effects of re-introducing fire to a central Florida sandhill community. Applied Vegetation Science 7:141-150

Roques KG, O'Connor TG, Watkinson AR (2001) Dynamics of shrub encroachment in an African savanna: relative influences of fire, herbivory, rainfall and density dependence. Journal of Applied Ecology 38: $268-280$ 
Simon MF, Grether R, de Queiroz LP, Skema C, Pennington RT, Hughes CE (2009) Recent assembly of the Cerrado, a neotropical plant diversity hotspot, by in situ evolution of adaptations to fire. Proceedings of the National Academy of Sciences U.S.A. 106:20359-20364

Streng DR, Glitzenstein JS, Platt WJ (1993) Evaluating season of burn in longleaf pine forests: a critical literature review and some results from an ongoing long-term study. Proceedings of the Tall Timbers Fire Ecology Conference 18:227-263

Trahan L, Bradley JJ, Morris L, Nolde R (1990) Soil survey of St. Tammany Parish, Louisiana. United States Department of Agriculture, Soil Conservation Service, Washington, D.C. http://soils.usda.gov/survey/ online_surveys/louisiana/ (accessed 2 Dec 2014)

Tu M, Hurd C, Randall JM, The Nature Conservancy (2001) Weed control methods handbook: tools \& techniques for use in natural areas. U.S. Government Documents (Utah Regional Depository). Paper 533. http://digitalcommons.usu.edu/govdocs/533 (accessed 15 May 2015)

Van Auken OW (2000) Shrub invasions of North American semiarid grasslands. Annual Review of Ecology and Systematics 31:197-215

Coordinating Editor: David Eldridge
Van Lear DH, Carroll WD, Kapeluck PR, Johnson R (2005) History and restoration of the longleaf pine-grassland ecosystem: implications for species at risk. Forest Ecology and Management 211:150-165

Walker JL, Silletti AM (2006) Restoring the ground layer of longleaf pine ecosystems. Pages 297-325. In: Jose S, Jokela EJ, Miller DL (eds) The longleaf pine ecosystem: ecology, silviculture, and restoration. Springer, New York

Ward D (2005) Do we understand the causes of bush encroachment in African savannas? African Journal of Range and Forage Science 22:101-105

Weakley A (2012) Flora of the southern and mid-Atlantic states. http://www. herbarium.unc.edu/FloraArchives/WeakleyFlora_2012-Nov.pdf (accessed 6 Mar 2015)

\section{Supporting Information}

The following information may be found in the online version of this article:

Appendix S1. Species list and their occurrences in the plots at the Abita Creek Preserve.

Received: 23 December, 2014; First decision: 3 February, 2015; Revised: 21 May, 2015; Accepted: 21 May, 2015; First published online: 3 July, 2015 